myślenie. G. von Rad nie zrealizował w pełni swojego „kanonicznego” programu. Mówi on na przykład w Torze nie o Pięcioksięgu ale o Sześcioksięgu, a Księgę Powtórzonego Prawa zalicza do „dzieła kapłańskiego”. Proroków przedstawia według chronologii ksiąg prorockich. Marginalizuje jednak „Pisma”, nie omawia wcale Ksiąg: Estery i Rut lub, że są one „odpowiedzią Izraela” na historyczne tradycje teologii Izraela.

R. Rendtorff jest bardziej konsekwentny. Jego układ opiera się nie tylko na trzy częściowym kanonie hebrajskim, ale i przedstawia teologiczne tematy poszczególnej księgi. Jego główną ideą jest przedstawienie trzech części kanonu i wskazanie różnic i związków między nimi ze szczególnym wskazaniem na przemawiającego Boga do niego ludu. Można powiedzieć, że w pierwszej części kanonu - Bóg działa, w drugiej Bóg mówi, w trzeciej — ludzie przemawiają do Boga i od Boga (s. 6). Według R. Rendtorffa następstwo trzech części kanonu odpowiada ich teologicznemu znaczeniu. Pięcioksiąg (Tora) stanowi podstawę życia i myślenia Izraela, dla jego rozumienia Boga i świata, dla jego samozrozumienia i reguł kultu, jako przejawu wiary i czci dla Jahwe oraz relacji między ludźmi. Według niego pozostałe części kanonu opierają się na Torze.

Ukazanie się tej „Teologii” jest ważnym krokiem w poznawaniu teologicznych wymiarów Starego Testamentu. Biblia izraelska otrzymuje tu swój teologiczny kształt. Ukazane są teologiczne tematy poszczególnych ksiąg Starego Testamentu, nie brak również ogólnego spojrzenia na teologiczny wymiar Słowa Bożego zawartego w Starym Testamencie.

Pisze tu teolog, który nie tylko zna Stary Testament ale ceni go wysoko i kocha, czuje się to jakby między wierszami tej książki, choć nie jest to łatwa lektura.

Teologia R. Rendtorffa nie jest tylko przedstawieniem treści ksiąg biblijnych Starego Testamentu, ale jest to w pełni książka teologiczna. Część pierwsza, przedstawiająca w dużej mierze treść poszczególnych Ksiąg Starego Testamentu jest „fundamentem” na którym autor rozwinie na pewno - w sposób pogłębiony teologiczne problemy Starego Testamentu, przedstawione już w części pierwszej.

Częstochowa

KS. ZDZISŁAW MALECKI

\title{
JOSEF SCHREINER, Das Alte Testament verstehen. Ergänzungsband zum Alten Testament, Wurzburg Echter Verlag 1999, s. 248.
}

Znane w Wurzburgu wydawnictwo Echter Verlag wydało nowa pracę prof. J. Schreinera - Das Alte Testament verstehen. Prof. J. Schreiner zajmuje się teologią biblijną i kolejna jego praca jest próbą dalszego wniknięcia w teologię i zrozumienie orędzia Starego Testamentu. Na kierunek badań tej pracy wskazuje już sam tytuł — Zrozumieć Stary Testament. Autor dzieli ją na trzy części: 


\section{A. Szczególna Księga:}

1) Różnorodne dzieło literackie;

2) Kanon Pisma Świętego;

3) Stary Testament i literatura współczesna jemu;

4) [Stosunek] Starego Testamentu i jego odniesienia do Nowego Testamentu;

5) Powstanie grup tekstów i pism.

B. Słowo Boże:

1) Słowo Boże;

2) Słowo wypowiedziane przez Boga;

3) Prawda i zaufanie.

C. Dostęp do Starego Testamentu:

1) Bez określonego zakończenia;

2) Znaczenie Nowego Testamentu;

3) Pytania Kościoła;

4) Późniejsze badania;

5) Badania pod różnymi pod różnymi aspektami;

6) Wieczność Słowa Jahwe.

Prof. J. Schreiner patrzy na Biblię z punktu widzenia teologii biblijnej, która chce interpretować całe orędzie biblijne i patrzeć na Stary i Nowy Testament jako na Słowo Boga skierowane do ludzi. Aby odpowiedzieć na postawiony w tytule problem rozumienia Starego Testamentu, trzeba pytać o historię Izraela lub historię jego religii, o środowisko w jakim żył. Badacz Starego Testamentu musi pytać o właściwy sens Starego Testamentu i stosować właściwa interpretację. Chodzi również o chrześcijańskie rozumienie Starego Testamentu. Te właśnie tematy chce podjąć prof. J. Schreiner w nowo wydanej pracy, aby dokonać pewnego kroku, na drodze lepszego wyjaśniania i rozumienia Słowa Bożego zawartego w orędziu Starego Testamentu Biblii wymaga ciągle nowej interpretacji.

Ta książka chce pomóc lepszemu zrozumieniu Starego Testamentu, jego powstania, treści, jego miejsca w literaturze światowej. Stary Testament ma wielkie znaczenie dla judaizmu i chrześcijaństwa a nawet islamu. Biblia jest podstawą życia religijnego chrześcijaństwa.

Druga część książki chce wyjaśnić, co Stary Testament mówi o jego istocie i jak to rozumie nauka Kościoła.

Trzecia część - Dostęp do Starego Testamentu, zajmuje się możliwościa zbliżenia się do Starego Testamentu, co dziś czynić, aby osiagnać odpowiednia interpretację Biblii. Chrześcijaństwo od poczatku próbowało wyjaśnić Stary Testament i określić jego znaczenie dla Kościoła. Stary Testament wart jest każdego wysiłku, który próbowałby przybliżyć zrozumienie tych świętych ksiag. Dzieła historyczne 
ukazują, jak należy patrzeć na przeszłość i na przyszłość w świetle zapowiedzi zbawczych. Przemawiał w swoim słowie, ale pozwalał i mówić ludziom. W różny sposób przekazuje Stary Testament swoje słowo. Bóg przemawia do tego, kto się na Niego otworzy, może trzeba zapytać z Ozeaszem - „... któż jest tak mądry, aby to pojąć i rozumny, aby to rozważył?" (Oz 14, 10a). To podwójne pytanie nie chce mówić o niemożliwości zrozumienia, ale wskazać na trudności interpretacji. Chcąc posłużyć się mądrością i zrozumieniem, aby poznać „drogi Jahwe”, tzn. wolę Boga w życiu pojedynczego człowieka i nie oddzielać Bożego działania w historii i życiu potocznym człowieka. Dalej prorok mówi: „Bo drogi Pańskie są proste” (Oz 14, 10b). Te drogi Jahwe można poznać nie tylko przez czytanie prorockich słów, ale całego Starego Testamentu. Każdy czytający Stary Testament powinien go rozumieć i pojmować, co chce mu powiedzieć Bóg przemawiający z kart Starego i Nowego Testamentu.

Temu chce służyć ta nowa książka prof. J. Schreinera, aby pomóc czytelnikom zrozumieć słowo Boże i wypełniać wolę Boga, który objawił ją na kartach obu Testamentów i pragnienie, aby ci, którzy w Niego wierzą, poznawali Jego wolę i ją wypełniali.

Częstochowa

KS. ZDZISEAW MAEECKI

\section{RICHARD LEBEAU, Une histoire des Hébreux. De Moüse à Jésus. Edi- tions Tallandier, seria Documents d'histoire, Paris 1998, s. 291 (wkladka ze zdjęciami - 8 stron i 4 plany Palestyny).}

Richard Lebeau, ur. w 1953 r. jest absolwentem paryskiej Ėcole Pratique des Hautes Etudes w zakresie egiptologii i historii starożytnego Bliskiego Wschodu. Stale współpracuje z renomowanymi periodykami, jak „Historia” i „Archeologia”. Jest autorem licznych publikacji i artykułów, m.in. Lettres et souvenirs de J. F. Champollion (Bourgois 1986) i Guide culturel Syrie-Jordanie (Arthaud 1996).

Książka Richarda Lebeau ukazuje dzieje Hebrajczyków w konfrontacji z tekstami Pisma Świętego. Od trzech tysięcy lat lud Izraela jest bowiem przedmiotem licznych kontrowersji i pytań. W oparciu o stulecie wykopalisk archeologicznych i wyniki nauk pomocniczych, jak egiptologia, asyriologia i filologia biblijna, autor dokonuje oryginalnej analizy historii Hebrajczyków - narodu wybranego - na ogromnej przestrzeni chronologicznej aż po wygnanie Żydów z Ziemi Świętej przez Rzymian w $135 \mathrm{r}$.

Wędrówka przez dzieje dawnego Izraela ma charakter chronologiczny sięgając w rozdziale I (Le Proche-Orient avant les Hébreux) okresu prehistorii Palestyny i Bliskiego Wschodu. Zasadnicze znaczenie ma jednak rozdział II (Les Origines des Hébreux) stanowiący analizę historii Patriarchów, szczególnie Abrahama, oraz 